\title{
Political Communication Competence of Women Legislators
}

\author{
Nurannafi Farni Syam Maela \\ Communication Science Department \\ Dr. Soetomo Univerity \\ Surabaya, Indonesia \\ nurannafi@unitomo.ac.id \\ Funny Mustika Elita \\ Communication Science Department \\ Padjadajaran University \\ Jatinangor, Indonesia
}

\author{
Edwin Rijal \\ Communication Science Department \\ Padjadajaran University \\ Jatinangor, Indonesia \\ Slamet Mulyana \\ Communication Science Department \\ Padjadajaran University \\ Jatinangor, Indonesia
}

\begin{abstract}
The representation of women in the 2014-2019 legislative election in Surabaya City reached $31 \%$. This represents that the people of Surabaya City already have awareness about gender equality in the public sphere. The trust and awareness of the Surabaya city community towards members of women's legislation is balanced with the ability of women legislators to be politically well-informed. Communication skills of women legislators will relate to their credibility in carrying out their duties as representatives of the people who support women. Some of the findings from this study explored that women's legislative political communication competencies are in line with the experience of the roles played by female legislators as seen from the aspect: the role of female legislative members as representatives of women's societies and representatives of feminists. Meanwhile, regarding political communication competencies derived from the ability within the female legislative members seen from the aspect of awareness of self-identity, motivation and self-confidence. Legislative members' political communication competencies with the parties involved, including cognitive aspects, socialization skills and adaptation. The communication competence of women legislators is related to how a female legislative member has the knowledge and skills in establishing relations and existence in the mass media.
\end{abstract}

Keywords_credibility; political communication; MPs; woman

\section{INTRODUCTION}

Through legislation concerning the determination of gender quotas, countries in various worlds have succeeded in increasing women's representation in the public sphere, especially in the political sphere. The quota in these countries ranges from $20 \%$ to $50 \%$. Worldwide, national gender quota laws generate an 8 percentage point increase in the number of women elected to parliament [1]. Likewise in the city of Surabaya, in 2014, it was able to achieve women's representation by $31 \%$. This represents the representation of legislative members in parliament, not only limited to fulfilling the representation quota that feminists have fought for in the west alone, but women's representation is a long and big process that every woman must pass when deciding to become a legislative member. Some women are not presentenced in decision-making bodies [2].

Representation of women in parliament is one of the advances that are expected to bring changes to the quality of legislation with a female perspective and a fair gender; changes in perspective in seeing and resolving political problems by prioritizing peace and anti-violence methods, changes in policies and legislation that contribute to the needs of women as part of the national agenda and make women empowered to be involved in various problems that have been not getting attention in Indonesia, which is gender sensitive. Other studies say that Women may be seen as bringing to politics their own perspectives, experiences, and expertise and are more likely than to introduce legislation regarding education, health, child care, and vulnerability against women [2]. This, will be an interesting breakthrough to be revealed scientifically, considering that women may have a different strategy than men. Numerous studies of there are several differences between male and female legislators in legislative behavior and policy preferences [3]. The involvement of women in politics and as representatives of the people means that women have become political actors who forced to have good political communication skills. Political communication is the process of delivering information (including facts, opinions, beliefs), where exchanges and searches are carried out by participants in the context of institutionalized political activities. Political communication functions to connect all parts of the political system, so that various aspirations and political interests can be converted into a policy.

In the time in Surabaya City, the issue of women's legislative members did not lie in the increasing number of 
women in parliament again but in reality often women DPRD members had to deal with other DPRD members who had not had a gender perspective. Not all women DPRD members realize that they are part of the struggle for gender equality that must continue to fight for gender equality. They do not realize their identity as gender fighters. The problems of female politicians are increasingly widespread, other problems encountered in the voice and activities of female politicians are less heard in the community. Of course seen from, media coverage of female politicians is minimal compared to media coverage of male politicians. As in the concept of communication, in the process of communication (politics) the mass media is a political communication channel that is very urgent. Considering that mass media is not only able to convey political information well but also the media is able to build an image and build public opinion. The lack of political communication processes carried out by women politicians will strengthen the notion that women politicians have never done for the community.

\section{METHOD}

The approach used is a phenomenological approach which intends to reveal as much detail as possible the object under study and other aspects that are not possible to be calculated with mathematics. Phenomenology is interested in identifying this problem from the world of sensory experience that is meaningful to a world full of meaningful objects. One thing that originally happened in separate individual consciousness but in interaction becomes collective consciousness. Schutz considers humans to be social beings, consequently awareness of daily life is a social awareness which according to him takes place in two ways: first, awareness to rely on other people's activities to be shared. Second, awareness uses types that are created and communicated by existing groups of individuals. Subjects in the study were all women legislators in the Surabaya City DPRD. His research was conducted with a qualitative approach. With the method of observation, interviews and literature study, it was conducted to 9 female legislators as informants. The characteristics of informants are women who have two periods of legislation, not limited to age, religion, party etc. Interviews are conducted using interview guidelines relating to the communication skills of women members validated with documents in the form of opinions that are often displayed by women legislators in various mass media. Observations were made on each legislative activity in the constituents and in the party on the commission's meetings, plenary meetings, and faction meetings.

\section{FINDINGS}

The patriarchal space has limited women's space in the public sphere. In 2014-2019 the city of Surabaya, one of the cities that had achieved women's representation in the legislature was more than 30\%. Different from other cities in Indonesia. Even so, not all women who are legislative members in the city of Surabaya all have the courage to communicate to voice the people's aspirations in the public sphere. The results of this study found that female legislators in the city of Surabaya still lack communication competence in the public sphere, this can be seen from their low existence in the media both mass media and social media. In the use of social media such as Facebook, Twitter, Instagram is not used as a political medium. Surely this social media can be used as a training ground for verbal and non-verbal communication. In the meeting activities, both the commission, plenary or faction meetings, still lacked participation in expressing opinions or leading opinions relating to women's welfare. Among the 17 legislative members, who were seen as active in the media or only 4 legislators, the rest chose to remain silent and follow a joint agreement. Not only that, in each of the activities held they tend to always choose jobs that do not require public speaking, such as secretaries, treasurers and others. This is motivated by: first, not all women legislators have experience in the field of organization, secondly: women legislative members are not cadres of the supporting party, which of course has gone through a regeneration process. Third, the lack of organizational experience and insight make women legsialtif members lack confidence, fourthly, not understanding their identity as legislative members who function as representatives of the people, party representatives and women's representatives.

\section{ANALYSIS}

The existence of affirmative action provides opportunities for women to work in public spaces and even take and influence policies through changes in laws that are friendlier to women and children. His power should increase women's opportunities to lobby for further support of women as candidates for parliament. [4] as the ruling party, women legislators have the opportunity to speak out expressing women's aspirations, in fact this is rarely done by women legislators. This is because of the lack of verbal communication skills carried out by female legislators. This research departs from the phenomenon and the stigma of "weak" the power of women legislators in the city of Surabaya seen from the side of the rarely or never heard of the role of women politicians in the mass media. Such as the stigma that is often raised by some journalists or the public, who still consider one eye the ability of women legsialtif members. When compared to a volume, the voice of a very small female politician is heard. Goffman defines a stigma as "an attribute that others perceive to be deeply discrediting" or less than human to non-stigmatized individuals, or normals [5].

Especially to be a resource person in the mass media, researchers see no or rarely female politicians appear. How do you want to fight for and be seen by women that there are parties who care and will fight for the rights of women if these women politicians have never been "heard" and are well known among women. Women legislative members function as representatives of the people, who voice the aspirations of the people, therefore women legsialtif members act as political communicators. Position as a member of the legislature gives 
a very strategic role, and becomes the foundation of hope of the people (followers) both those who vote for them in the election and those who do not vote. The consequence of this is that female legislative members must have political communication competencies that will be judged based on the criteria expected from the people's representatives. The success of a legislative member in establishing policies that care for women and have good achievements as female politicians. Political rhetoric conveyed in a political situation is always laden with language, strategies and expectations built on the tradition of political discourse dominated by male speakers and norms mediated by men. In the political world it takes courage, independence, freedom of opinion and aggressive action. So when women enter the political realm, women must be prepared to be bolder, independent and aggressive by leaving behind the emotional aspects that always dominate women.

Women and men when they enter the political world have the same opportunities to be able to compete in a way that has good competence. Men and women can contribute in a balanced and optimal way in political, social, economic, cultural and religious development and both can enjoy the results in a women's perspective. Richard Heffernan has argued that 'prime ministerial studies' must factor in the prime minister's personality and style, describing and analyzing prime ministers, and taking account of their personal skills and abilities [6, pp. 615-617]. Therefore, some academics and many practitioners still believe that communication competence is a behavior that can be measured in a long period of time.

In its terms, it is usually called "broadcast hours" the more it trains its abilities, the more it will increase its competence in political communication. Communication competence will determine the success of a politician in conveying each of his ideas. This can lead a politician to his success. Furthermore, communication is an important factor in the success of everyone's life. This is in line with the presentation of Devito that fear in communication is influenced by lack of skills and experience in organizing. The more a person follows the organization, the more experience he gets in communicating with other people, so that his skills are further honed. In an organization, the individual is faced with a situation where he must communicate in front of a large number of people, face others who disagree with what he says or have different opinions. The more often someone is faced with situations like this, the more he is trained to be able to effectively deal with the situation so that his skills in interpersonal communication will get better.

The daily life of politicians is to live from stage to stage. From time to time politicians are always required to be present on the front stage to show their formal role. In political communication, which is always synonymous with the front stage and the back stage of individual communication skills are things that can be trained and planned in accordance with the objectives expected by each legislative member. Especially when politicians are on the front stage, they must really pack communication very effectively, so that the desired results are effective. The politicians must be well aware that as a political communicator the representatives of their people have a broad interaction in developing their role. Therefore, understanding the context of communication is one of the keys to the effectiveness of communication. In the case of US presidential debates, the author argues that J.F. Kennedy's image of a strong leader, something that was communicated through his appearance and general manner [7].

Political communication competency of women politicians is not only studied on one side where female politicians are considered capable of "appearing" on the front stage as do male politicians, but political communication competencies will be assessed through intrapratic communication competencies in female politicians and female politician interpersonal competencies to the environment.

\section{CONCLUSION}

Communication competence of women legislative members in Surabaya City is still weak despite the $31 \%$ representation being achieved. Political communication competencies can be trained with frequent arguments in each situation, during meetings (plenary, fraction, commission), when capturing aspirations (recess), and at the time of constituent or party activities. Furthermore, contributing thoughts can be a speaker in a media, institution or community. To increase self-confidence can be done by making an understanding of his identity as a representative of the people.

\section{SUGGESTION}

The results of this study must be investigated further by conducting research that uses a wider range of approaches and is carried out in various places, not only in Surabaya, but throughout Indonesia. This is done so that there is a picture and comparison in accordance with the local geographic location. Because local cultural factors greatly influence my individual behavior.

\section{ACKNOWLEDGEMENT}

The researcher expressed gratitude to media crews in the city of Surabaya who have helped provide an understanding of the research study.

\section{REFERENCE}

[1] L. Baldez, "Elected bodies: The gender quota law for legislative candidates in Mexico," Legis. Stud. Q., vol. 29, no. 2, pp. 231-258, 2004.

[2] A. M. Tripp and A. Kang, "The global impact of quotas: On the fast track to increased female legislative representation," Comp. Politics. Stud., vol. 41, no. 3, pp. 338-361, 2008.

[3] M. P. Jones, "Quota legislation and the election of women: Learning from the Costa Rican experience," J. Polit., vol. 66, no. 4, pp. 12031223, 2004.

[4] M. Caul, "Women's Representation in Parliament," Party Polit., vol. 5, no. 1, pp. 79-98, 1999.

[5] N. Ellemers, R. Spears, and B. Doosje, "S Elf and S Ocial I Dentity," Group, vol. 53, no. 1, pp. 161-186, 2002.

[6] K. Theakston, "Gordon Brown as prime minister: Political skills and leadership style," Br. Polit., vol. 6, no. 1, pp. 78-100, 2011.

[7] K. Budd, "Analyzing political speeches: rhetoric, discourse and metaphor," vol. 5904, January 2016. 